\title{
Dylematy związane z włączaniem uczniów dyslektycznych do systemu edukacji
}

\section{Streszczenie}

Celem niniejszego artykułu jest prezentacja możliwości włączania uczniów dyslektycznych w proces kształcenia w szkołach głównego nurtu. Tekst stanowi przegląd zestawu zasad pozwalających na lepsze funkcjonowanie dyslektyków w systemie szkolnictwa. Przedstawiono również całościowy obraz współpracy pomiędzy specjalistami szkolnymi, nauczycielami i rodzicami uczniów dyslektycznych.

Słowa kluczowe: dysleksja, włączanie, uczniowie ze specjalnymi potrzebami edukacyjnymi, język angielski jako język obcy, język angielski jako drugi język, język angielski jako język dodatkowy

\section{Włączenie}

Modele włączenia wynikają ze spojrzenia na trudności w uczeniu się w szczególności $\mathrm{z}$ dysleksją. Termin spoleczny model niepetnosprawności (Oliver, 1981) doprowadził do usunięcia etykiet i szkolnictwa specjalnego pod koniec XX wieku, gdy uczniowie ze specjalnymi potrzebami zaczęli być włączani do szkół głównego nurtu (Armstrong, Squires, 2015).

Celem edukacji włączającej jest wsparcie uczniów (Ainscow, 2000). W ostatnim dwudziestoleciu liczba ogłoszeń dotyczących włączania została ustalona na poziomie międzynarodowym (The Salamanca Statement and Framework for Action on Special Education, 1994; World Education Forum in Dakar, Senegal, 2000). W 1994 roku w oświadczeniu Salamanca (The Salamanca Statement and Framework for Action on Special Education, 1994) wprowadzono pojęcie orientacja włączająca, zgodnie z którym wszystkie dzieci 
mają prawo do edukacji i powinny mieć dostęp do szkół głównego nurtu. Następnie, w 2000 roku, potrzeba rozwoju międzynarodowego włączenia została usprawniona wraz z oświadczeniem Światowego Forum Edukacji sugerującym, że włączenie uczniów z trudnościami to ,priorytet krajowy i międzynarodowy" (World Education Forum in Dakar, Senegal, 2000: 17).

Powyższe inicjatywy, chociaż znaczące, osiągnęły swój cel tylko w pewnym stopniu (O’Brien, 2001). Włączanie to kłopotliwe pojęcie (Pearson, 2001), a sposób jego realizowania w różnych systemach edukacyjnych w dużym stopniu zależy od czynników kontekstualnych (tj. systemu edukacji, charakterystyki szkoły itp.).

\section{Dysleksja a włączanie}

Włączanie stanowi dynamiczny proces, w którym uwzględniane są różne potrzeby ucznia, ustalane wyzwania w nauce oraz pokonywane bariery uczenia. Włączanie uczniów z dysleksją odnosi się do odpowiedzialności systemów szkoły oraz edukatorów, aby pomóc uczniom dyslektycznym ocenić program nauczania.

W celu osiągnięcia włączania nauczyciele powinni oprzeć swoje praktyki na charakterystyce dyslektyków i nauczać ich w taki sposób, w jaki uczą się sami dyslektycy. Adaptowanie programu nauczania do potrzeb uczniów dyslektycznych usprawnia ich włączanie, podnosi ich samoocenę i wpływa na poprawę ich wyników.

Termin wynik w edukacji zwykle odnosi się do akademickich wyników uczniów. Na poziomie szkolnym wyniki akademickie uczniów są relewantne względem wyników edukacyjnych eksplorowanych poprzez narzędzia ewaluacji i oceny nauczyciela (na przykład testy). W przypadku uczniów dyslektycznych duży nacisk kładzie się na dostępność do programu nauczania, wyników w zadaniach piśmiennych (czytanie, ortografia), podczas gdy istnieją przypadki, że ich wyniki w pozostałych obszarach (na przykład mowa, umiejętność liczenia) są również eksplorowane. Z powodu ich złożoności dysleksja może znacząco wpływać na postęp edukacyjny oraz osiągnięcia uczniów. Chociaż wyniki uczniów są silnie związane z ich włączaniem, wiele badań skupia się raczej na zasadach włączania niż wpływie tych zasad na uczniów dyslektycznych oraz ich rówieśników. Potrzebne są więc badania, które pokażą wpływ prób włączania na wyniki uczniów głównego nurtu (dyslektyków i uczniów bez dysleksji), aby określić takie zalecenia dotyczące nauczania, z których skorzystają wszyscy uczniowie.

Oprócz obszaru wyników głównym obszarem obaw w badaniu dysleksji jest niski poziom samooceny uczniów dyslektycznych. Samoocena odnosi się do porównań przekonań, które mają o sobie poszczególne osoby. W szkole głównego nurtu uczniowie z dysleksją częstokroć doświadczają uczucia stresu, porażki, zażenowania. Często rówieśnicy znęcają się nad nimi, szczególnie gdy są dokonywane porównania z ich rówieśnikami bez dysleksji. Wszystkie te czynniki w połączeniu z ustandaryzowanymi normami edukacyjnymi i kulturowymi, jak też pozostałe uwarunkowania społeczne (na przykład środowisko uczniów) mogą obniżyć samoocenę uczniów dyslektycznych.

Innym aspektem związanym z obszarem włączania uczniów dyslektycznych jest poczucie własnej skuteczności takich uczniów. Uczniowie ci ze względu na swoje trudności są 
narażeni na niski poziom poczucia własnej skuteczności, co prowadzi do ograniczonego uczestnictwa w zadaniu oraz do zmniejszonej kompetencji osobowej. Zadania piśmienności wzbudzają niepokój u uczniów z dysleksją i skutkują oczekiwaniami niskich wyników w kontekstach szkolnych. Ponadto uczniowie z trudnościami w uczeniu się wykazują tendencję do internalizacji swoich porażek oraz przypisywania niskich wyników swoim niskim umiejętnościom. Wszystkie te czynniki w sposób negatywny wpływają na włączanie uczniów dyslektycznych i ich wyniki oraz powodują uczucie segregacji w kontekstach szkoły głównego nurtu.

\section{Doświadczenia nauczyciela z włączaniem}

W badaniach poświęconych włączaniu oprócz obszarów eksploracji związanych z uczniami analizowane są poglądy nauczycieli na temat włączania, które mają wpływ na pomyślność rozwoju włączeniowego. Odpowiedź nauczycieli na próby włączania to przedmiot powszechnej charakterystyki w odnośnych badaniach.

Jednym z najważniejszych czynników wpływających na poglądy nauczycieli na temat włączania jest szkolenie, które nauczyciele odbywają w obszarze niepełnosprawności. Model społeczny niepełnosprawności zwiększył obecność uczniów ze specjalnymi potrzebami edukacyjnymi w szkołach głównego nurtu pod koniec XX wieku, a potrzeba szkolenia nauczycieli w zakresie SEN wzrosła. Dowody skuteczności różnego rodzaju programów (na przykład zaprogramowany pojedynczy przedmiot lub zaprogramowana systematyczna infuzja), które przygotowują nauczycieli do włączania, wciąż są skąpe. Jednakże nacisk na strategie praktyczne i refleksyjną praktykę wykazał obniżenie obaw nauczycieli związanych z wdrożeniem praktyk włączających. Gdy nauczyciele są proszeni, żeby uczyć uczniów z niepełnosprawnościami, często zgłaszają problemy, takie jak brak czasu, zwiększony nakład pracy oraz brak źródeł. Ważne są tu szkolenia nauczycieli, które umożliwiają im zrozumienie charakteru niepełnosprawności, zwiększają ich pozytywny stosunek do wdrażania programów włączających.

Charakterystyka kontekstualna wpływa na efektywność i stosunek nauczycieli do włączania, jako że kontekst definiuje stopień, w którym uczniowie osiągają świadomość oraz doświadczenie rozwoju włączającego. Wielu badaczy twierdzi, że nauczyciele powinni posiadać możliwość angażowania się w owocny kontakt z osobami z niepełnosprawnościami oraz uzyskiwać bezpośrednie doświadczenie w zakresie pomyślnych modeli włączania. Nauczyciele mają tendencję do wykazywania pozytywnego stosunku wobec włączania, jeśli idzie to w parze ze wsparciem rządu. Z drugiej strony brak programów szkoleń nauczycieli oraz funduszy na wsparcie utrudnia nauczycielom osiągnięcie skuteczności w nauczaniu uczniów z niepełnosprawnościami. Na przykład Molto stwierdził, że ograniczone doświadczenie nauczycieli w dziedzinie włączania skutkowało odczuciem przez nauczycieli szoku kulturowego, gdy zostali poproszeni o zaadaptowanie swoich strategii nauczania. Co więcej, ograniczona świadomość nauczycieli w zakresie badania Molto skutkowała kwestionowaniem przez nich skuteczności adaptacji instruktażowej do klas włączeniowych. Na skuteczność nauczyciela wpływa także sposób, w jaki wdrażane 
są interwencje o włączanie. Interwencje, które pozwalają nauczycielom na dokonywanie decyzji, podnoszą ich pewność siebie oraz wpływają pozytywnie na próbę włączania.

Innymi czynnikami, które decydują o skłonności do eksperymentowania i podejmowania ryzyka związanego z włączaniem, są charakterystyka osobowości nauczycieli, ich przekonania, poziom pewności siebie oraz doświadczenie. Również sposób, w jaki nauczyciel definiuje oraz odbiera niepełnosprawność, wpływa na jego nastawienie do prób włączania. Badanie wykazało, że nauczyciele, którzy postępują zgodnie z podejściem interwencyjnym, a nie medycznym do niepełnosprawności, czują się bardziej odpowiedzialni w postępowaniu wobec trudności uczniów oraz są orędownikami prób włączania.

\section{Dysleksja a uczenie się języka}

Trudności wynikające z dysleksji są uniwersalne i chociaż transparentność języka może wpływać na manifestacje dysleksji, problemy uczniów dyslektycznych z piśmiennością będą się utrzymywały. Potrzeba uczenia się języka w dzisiejszym społeczeństwie wymaga zapewnienia dyslektykom dostępu do językowego programu nauczania. Istnieją badania nad identyfikacją dysleksji oraz wsparciem dyslektyków uczących się języka, a obszary te będą poddawane dalszym analizom. Kolejne rozdziały poświęcone są omówieniu badań z zakresu dysleksji i uczenia się języka jako drugiego języka oraz języka obcego.

\section{Włączenie dyslektyków w naukę języka}

Ogromny obszar badań związany jest z włączaniem uczniów dyslektycznych w kontekstach monolingwalnych. Istnieją nierówności w ramach obszaru włączania. Pomimo faktu, iż żyjemy w zglobalizowanym społeczeństwie, a dzisiejszą populację świata stanowi więcej osób multilingwalnych niż monolingwalnych, badanie nad włączaniem często pomija silną obecność lingwistycznie odmiennych uczniów w edukacji. To samo dotyczy obszaru nauczania języka obcego. Niedostateczne zbadanie obszaru włączania w edukację języka skutkowało ograniczonym szkoleniem nauczycieli w dziedzinie dysleksji. W konsekwencji nauczyciele języków mogą nie nadążać za procesami włączania oraz wzrostem zróżnicowania klasowego.

Oprócz nauczycieli języków także uczniowie dyslektyczni uczący się języka napotykają bariery w dostępie do językowego programu nauczania, wynikające z trudności w obszarach związanych z językiem (na przykład świadomości fonologicznej). Co więcej, ustandaryzowane środki oceny oraz fakt, iż systemy edukacji zazwyczaj zakładają jednorodność wśród uczniów, ograniczają możliwości uczniów dyslektycznych w zakresie akwizycji umiejętności językowych. Zatem chociaż istnieją przypadki, gdy obserwujemy korzyści z uczenia się języka przez uczniów z trudnościami (na przykład rozwijanie myślenia elastycznego), to przeważnie dyslektycy natrafiają na trudności w uczeniu się języków świata, takich jak język angielski, i odpowiedzi na nowe formy globalizacji (na przykład analfabetyzm cyfrowy). Więcej badań nad wsparciem dyslektyków w kontekstach 
językowych ma na celu poinformowanie nauczycieli o sposobie odpowiedzi na potrzeby uczniów dyslektycznych oraz promowania ich włączania do kontekstów językowych.

\section{Identyfikacja dysleksji dla uczniów języka}

Szerokie skupienie na umiejętności kognitywnej jest oczywiste w obszarze identyfikacji dysleksji dla uczniów języka (dwujęzycznych/języka obcego/drugiego języka). W obszarze języka angielskiego jako języka obcego oraz dysleksji, jeżeli język jest głównie nauczany w klasie, większość badań posiada wpływ paradygmatu psycholingwistycznego. Proces uczenia się języka jest zatem postrzegany głównie jako akwizycja konkretnych umiejętności (czytanie, słuchanie, mówienie oraz pisanie). Również środki oceny w odniesieniu do uczących się języka mają tendencję do ignorowania czynników społecznych, kulturowych oraz językowych, wpływających na rozwój umiejętności uczniów wielojęzycznych/dwujęzycznych. W Zjednoczonym Królestwie gdy na przykład uczniowie EAL używają języka w szkole oraz poza nią, ich ocenianie odbywa się w języku angielskim. To powoduje, że procesy oceniania są kulturowo oraz lingwistycznie stronnicze.

Ocena dwujęzycznych oraz wielojęzycznych uczniów dyslektycznych jest kluczowym wyzwaniem dla edukatorów, jako że różnice wielojęzykowe (na przykład transparentne/ nieprzejrzyste ortografie), charakterystyka konkretnego ucznia oraz aspekty kulturowe dodatkowo wpływają na proces nauki języka drugiego/obcego. Również trudności uczniów dyslektycznych uważane są czasem za problemy raczej językowe niż powiązane z ich dysleksją.

Chociaż identyfikacja dysleksji dla uczącego się języka jest problematyczna, została ona poddana obszernym badaniom, co pomogło lepiej zrozumieć trudności dyslektyków będących jednocześnie użytkownikami dwu bądź wielu języków. Badania empiryczne na temat dysleksji oraz nauki drugiego języka wykazały, że uczniowie dyslektyczni będący użytkownikami drugiego języka nadal walczą z ortografią oraz umiejętnością czytania i że potrzebna jest ocena umiejętności rozpoznania słowa oraz skuteczności czytania słowa u uczniów drugiego języka. Wykazano ponadto problemy artykulacyjne podczas uczenia się przez uczniów z dysleksją języka drugiego. Podobne wyniki odnotowano w badaniach w przypadku, gdy uczniowie pierwszego języka są nieanalfabetyczni.

Identyfikacja dysleksji u uczniów wielojęzycznych/dwujęzycznych stanowi zawiły proces. Błędy, które popełniają uczniowie EAL, są podobne do charakterystyki dysleksji i w zależności od ortografii języka (na przykład transparentnej/nieprzejrzystej) uczniowie borykają się z dodatkowymi wymogami nauki wizualnej. Chociaż niektóre badania pokazały, że uczniowie dwujęzyczni wykazują mocne strony w obszarach świadomości fonologicznej, biegłości oraz elastycznego myślenia, słabe strony fonologiczne to mechanizmy uczenia się uczniów dyslektycznych, które będą się utrzymywały bez względu na system językowy. Te słabe strony mogą upośledzać rozwój czytania, pisania uczących się języka oraz w pewnych przypadkach - umiejętności generowania mowy w ustawieniach drugiego języka oraz języka obcego.

Co więcej, bariery kulturowe i społeczne (na przykład nierówności w ustawieniach różnorodności lingwistycznych) będą ograniczały rozwój umiejętności. Jedynie niewiele 
badań w obszarze identyfikacji dysleksji u uczniów wielojęzycznych/dwujęzycznych skupiało się na elementach środowiskowych (na przykład odpowiedziach uczniów na interwencję). Badania pokazują doświadczenia uczących się języka oraz wpływu na ich umiejętności w zakresie piśmienności. Dodatkowo czynniki wpływające (na przykład samoocena) oraz stosunek do języka docelowego oddziałują na rozwój języka u uczniów dyslektycznych. W edukacji monolingwalnej badania sugerują, że ograniczony rozwój umiejętności piśmienności uczniów dyslektycznych może być spowodowany nieodpowiednim wsparciem oraz niewłaściwymi praktykami edukacyjnymi. To wskazuje na implikacje dotyczące identyfikacji dysleksji (oraz wsparcia) uczących się języka. Należy również zauważyć, że znaczenie pojęcia uczenie się języka może być odmiennie rozumiane, ponieważ istnieją różnice pomiędzy uczeniem się języka obcego drugiego i dodatkowego. W wyniku istnieją warianty nauki języka obcego dla ucznia, ma on możliwość rezygnacji z dodatkowych godzin. Pojęcie język obcy oznacza, że język jest nieużywany w danym kraju lub na danym terenie, tym samym ważne jest nauczanie dodatkowego języka w szkole, w klasie.

\section{Podejścia w zakresie wsparcia dla uczniów dyslektycznych}

Podejścia w zakresie wsparcia dla uczniów dyslektycznych zostały opisane w badaniu nad identyfikacją dysleksji u uczniów dwujęzycznych/wielojęzycznych oraz uczniów dyslektycznych będących użytkownikami języka obcego, języka drugiego albo języka dodatkowego. U uczniów dyslektycznych poprawa umiejętności fonologicznej jest widoczna w badaniach nad dysleksją w konfiguracjach: język angielski jako język obcy, język angielski jako język drugi, język angielski jako język dodatkowy. Proponowane podejścia w zakresie wsparcia dla uczniów dyslektycznych zwykle obejmują bezpośrednie polecenie, nauczanie syntetyczne, analityczne oraz diagnostyczne. Korzystanie z konkretnych technik, takich jak operacje werbalne na niższym poziomie, kojarzenie pierwszego języka docelowego bądź powiązania dźwięk-symbol, jest również usprawniane. Podejścia w zakresie wsparcia, które biorą pod uwagę czynniki społeczne oraz środowiskowe, wpływające na dwujęzyczne/wielojęzyczne umiejętności uczniów, umożliwiają nauczycielom odpowiedź na różnice wśród uczniów oraz usprawniają włączanie uczniów dyslektycznych do klas językowych. Wiele badań w obszarze języka angielskiego jako języka obcego czy języka angielskiego jako języka dodatkowego pozwoliło określić podejścia do nauczania, które są pomocne dla uczących się języka angielskiego z dysleksją.

Nauczanie wielozmysłowe jest jedną z najpopularniejszych praktyk w obszarze wsparcia dysleksji w kontekstach językowych. Podejście wielozmysłowe obejmuje wykorzystanie różnych zmysłów w procesie uczenia (na przykład wizualne, dotykowe, kinetyczne), które mają znaczenie w poprawie świadomości fonologicznej uczących się języka angielskiego jako dodatkowego. Badanie sugeruje również, że techniki wielozmysłowe połączone z nauczaniem bezpośrednim stanowią korzyść dla dyslektyków będących użytkownikami wielojęzycznymi/dwujęzycznymi w kontekstach języka obcego oraz języka drugiego. 
Podejścia do nauczania, które wspierają dyslektyków uczących się języków, mogą także wspierać wszystkie osoby uczące się języków. Jednakże wdrożenie i ocena praktyki włączającej są potrzebne w celu poprawy konceptu włączenia w obszarze nauczania języka. To prowadzi do podejmowania dalszych badań, które skupiają się na ocenie praktyk włączających w klasach językowych.

\section{Badania empiryczne dotyczące wsparcia dyslektycznego dla uczących się języka}

Interwencje dyslektyczne, które miały miejsce w kontekstach nauki języka, pozwoliły na ocenę wpływu konkretnych praktyk na uczniów dyslektycznych uczących się języka. Literatura sugeruje, że interwencje, które odpowiadają potrzebom uczniów dyslektycznych, zapewniają pomoc tym uczniom w pokonaniu trudności. Jednoznaczna instrukcja, wykorzystanie ICT, bodźców słuchowych i wizualnych oraz pozytywnego wzmocnienia to niektóre ze wspierających podejść, które zostały uznane za skuteczne u uczących się języka angielskiego jako drugiego. Badania związane z interwencją w różnych kontekstach języka angielskiego (tj. język angielski jako język drugi, język angielski jako język dodatkowy, język angielski jako język obcy) dostarczyły ważnych informacji na temat skuteczności podejść głównie poprzez rozpoznanie ich wpływu na uczniów dyslektycznych. Wyniki tych badań oparte są na odpowiedzi dyslektyków na konkretne praktyki, które były wprowadzone w klasie lub w sesjach indywidualnych.

Z powodu rozpowszechnionego użycia języka angielskiego we współczesnym świecie interwencje dyslektyczne w edukacji językowej miały miejsce w klasach języka angielskiego (język angielski jako język dodatkowy, język angielski jako język drugi, język angielski jako język obcy). W większości badań nad dysleksją oraz nauką języka najczęściej odnotowywano pozytywny wpływ ICT, technik wielozmysłowych oraz bezpośredniego nauczania na umiejętności czytania i ortografii dyslektyków będących użytkownikami języka obcego/języka dodatkowego.

Wykorzystanie ICT oraz metod multimedialnych wspiera uczniów z dysleksją w klasach językowych. Przeanalizowano zastosowanie konkretnego oprogramowania w badaniach empirycznych nad wspieraniem dysleksji w ustawieniach EAL. Można na przykład skorzystać z dwóch dedykowanych programów, Nessy oraz Rapid Reading, które poprawiają umiejętność czytania uczniów dyslektycznych uczących się języka angielskiego jako języka dodatkowego. Oprócz korzystnego wpływu tych programów na dyslektyków będących uczniami języka angielskiego jako języka dodatkowego asystenci nauki w szkole zauważyli pozytywne oddziaływanie interwencji oraz szkolenia. Wpisując się w ten kontekst, ICT zwiększyło wyniki dwujęzycznych dyslektyków. Przy użyciu ICT ulepszane są również, poza wynikami, afektywne czynniki, takie jak motywacja. $\mathrm{Na}$ przykład używanie technologii mobilnej zwiększyło motywację uczniów dyslektycznych w Bułgarii, Rumunii, Szwecji oraz na Węgrzech.

Co więcej, stosowanie podejść związanych z wielozmysłowością oraz nauczaniem bezpośrednim może pomóc uczniom dyslektycznym będącym użytkownikami języka 
dodatkowego podczas napotkania trudności. W badaniach empirycznych w kontekście języka angielskiego jako obcego wykazano, że korzystanie z urządzeń wielozmysłowych oraz oczywistych technik nauczania i mnemonicznych znacząco poprawia słownictwo dyslektyków będących użytkownikami języka obcego. Morfidi i Reason (2000) dowiedli, że słabe wyniki czytelnicze w przypadku języka obcego znacząco poprawiły się po szkoleniu z fonetyki. Przykłady praktyk, które stosowali Morfidi i Reason, to aliteracje, łączenie dźwięków oraz szkolenie w zakresie rozpoznawania liter i pisania podczas godzinnych zajęć z piśmiennictwa dla uczniów w klasie.

W Polsce Nijakowska (2010) przeprowadziła badanie eksperymentalne, które wykazało, że korzystanie z nauczania bezpośredniego i wielozmysłowego poprawiło umiejętności czytania słowa oraz ortografię dyslektyków będących użytkownikami języka obcego, szczególnie podczas dokonywania asocjacji grafem-fonem. Podobnie Sparks (Sparks i in., 1998) dowiódł, że wielozmysłowy strukturyzowany język nauczania potwierdził swoją użyteczność w przypadku hiszpańskich uczniów języka obcego o wysokim ryzyku.

$\mathrm{Z}$ powodu faktu, że powyższe badania miały miejsce w faktycznych kontekstach klasowych, w niektórych z nich zostały wzięte pod uwagę czynniki kontekstualne (na przykład kontekst edukacyjny) lub elementy osobiste (na przykład etniczność, wiek), które wpływają na procesy uczenia. Na przykład Morfidi i Reason (2000), którzy przeprowadzili badanie wśród słabych czytelników języka angielskiego jako dodatkowego, uważnie przeanalizowali uzyskane wyniki, uwzględniając to, że język nauczania oraz czynniki społeczno-ekonomiczne wpłynęły na wyniki uczniów. To stanowi pretekst do dalszych badań dotyczących ,wrażliwości na kontekst” w obszarze dysleksji i nauki języka oraz do eksploracji skutków, jakie niosą czynniki kontekstualne (na przykład system edukacji, charakterystyka społeczna i kulturowa), na podstawie rozwoju językowego uczniów dyslektycznych.

\section{Praktyki przyjazne dysleksji}

Szkoły przyjazne dysleksji powstały w odpowiedzi na problemy związane z identyfikacją oraz wsparciem uczniów dyslektycznych w Zjednoczonym Królestwie. Celem szkół przyjaznych dysleksji było wypełnienie luki pomiędzy polityką a praktyką dotyczącą włączenia uczniów dyslektycznych. W późnych latach dziewięćdziesiątych XX wieku w Swansea pojawiły się liczne niepokojące opinie o dysleksji, a rodzice byli niezadowoleni ze sposobu, w jaki ich dzieci z dysleksją były wspierane w szkołach (Riddick, 2006). Na skutek tego Swansea Education Authority zrewidowało swój pogląd na temat wsparcia w zakresie dysleksji oraz doprowadziło do zorganizowania we współpracy z British Dyslexia Association konferencji poświęconej dysleksji. Następstwem tych działań było utworzenie Forum Szkół Przyjaznych Dysleksji, które pracowało na rzecz rozwoju polityki szkolnej zwiększającej włączanie dzieci dyslektycznych (lata 1997-2001). W 2001 roku ustanowiono ideę polityki szkolnej przyjaznej dysleksji. Trzy lata później zainicjowano projekt pilotażowy, w którym 25 LEA przyjęło podejście przyjazne dysleksji, mające na celu zapewnienie dobrego modelu skutecznego wsparcia dysleksji w szkołach. Z uwagi na 
fakt, iż wyniki tej inicjatywy były pozytywne, w 2005 roku British Dyslexia Association przyjęła praktyki przyjazne dysleksji i przyjazny dysleksji.

Pakiet szkół przyjazny dysleksji stanowi podręcznik źródłowy, w którym są oferowane porady, wskazówki oraz praktyki dotyczące sposobu rozwoju szkół przyjaznych dysleksji. Zgodnie z podejściem przyjaznym dysleksji uczniowie dyslektyczni są rozpoznawani jako posiadający trudności z pewnymi umiejętnościami. Celem jest pomoc w osiągnięciu przez nich sukcesu poprzez kombinację ukierunkowanych działań oraz zmian środowiskowych. Aby szkoła stała się przyjazna dysleksji, potrzebne jest całościowe objęcie wszystkich uczniów badaniami, oceną oraz monitorowaniem. Ponadto w takiej szkole wymagane jest wykorzystanie zasobów przyjaznych dysleksji, zaangażowanie rodziców oraz szkolenie nauczycieli. Kadrę pedagogiczną powinni stanowić specjaliści w dziedzinie dysleksji.

\section{Bibliografia}

Achieving Dyslexia-friendly Schools (2005), British Dyslexia Association, Oxford.

Ainscow M. (2000), Reaching out to all learners: Some lessons from international experience, „School Effectiveness and School Improvement”, Vol. 11(1).

Ainscow M., Sandill A. (2010), Developing inclusive education systems: the role of organip zational cultures and leadership, ,International Journal of Inclusive Education”, Vol. 14(4).

Anthony J.L., Francis D.J (2005), Development of phonological awareness, „Current Directions in Psychological Science", Vol. 14(5).

Armstrong D., Squires G. (2015), Key perspectives on dyslexia and essential text for educae tors, London.

Booth T., Ainscow M. (2002), Index for inclusion: developing learning and participation in schools, Bristol.

Brunswick N. (2012), Dyslexie, Legasthenie, Ordblindhed: Dyslexia in different languages, [w:] J. Everatt (red.), Dyslexia, languages and multilingualism, Bracknell.

Clark C., Dyson A., Millward A., Robson S. (1999), Theories of Inclusion, Theories of Schools deconstructing and reconstructing the "inclusive school”, „British Educational Research Journal", Vol. 25(2).

Ganschow L., Sparks R.L., Javorsky J. (1998), Foreign Language Learning Difficulties: An Historical Perspective, „Journal of Learning Disabilities”, Vol. 31(3).

Morfidi E., Reason R. (2000), The Effects of literary hour and phonics teaching on poor readers' phonological and literacy skills studies of children with English as an additional language, [w:] L. Peer, G. Reid (red.), Multilingualism, Literacy and dyslexia: A Challenge for Educators, London.

Molto M.C.C. (2003), Mainstream teachers'acceptance of instructional adaptations in Spain, „European Journal of Special Needs Education”, Vol. 18(3).

Nijakowska J. (2008), An experiment with direct multisensory instruction in teaching word reading and spelling to Polish dyslexic learners of English, [w:] J. Kormos, E.H. Kontra (red.), Language Learners with Special Needs. An International Perspective, Bristol.

Nijakowska J. (2010), Dyslexia in the foreign language classroom, Bristol. 
O'Brien T. (2001), Enabling inclusion: where to now?, [w:] T. O'Brien (red.), SEN Leadership: Enabling Inclusion, Blue Skies... Dark Clouds? Professional excellence in Schools, London.

Oliver M. (1981), A New Model of the Social Work Role in Relation to Disability, [w:] J. Campling (red.), The Handicapped Person: a New Perspective for Social Workers, London.

Pearson S. (2001), Inclusion: developmental perspective, [w:] T. O’Brien (red.), SEN Leadership: Enabling Inclusion, Blue Skies... Dark Clouds? Professional excellence in Schools, London.

Riddick B. (2006), Dyslexia - friendly schools in UK, „Topics in Language Disorders”, Vol. 26, No. 2.

Sparks R.L., Artzer M., Patton J. Ganschow L., Miller K., Hordubay D.J., Walsh G. (1998), Benefits of multisensory structured language instruction for at-risk foreign language learners: A comparison study of high school Spanish students, „Annals of Dyslexia”, Vol. 48(1).

The Salamanca Statement and Framework for Action on Special Education (1994), United Nations Educational, Scientific and Cultural Organization (UNESCO), Paris.

World Education Forum in Dakar, Senegal (2000), United Nations Educational, Scientific and Cultural Organization (UNESCO), Senegal.

\section{Abstract \\ Dilemmas related to the inclusion of dyslexic students into the education system}

The aim of the article was to present opportunities to include dyslexic students into the process of education in mainstream schools. The text constitutes an overview of a set of rules to allow for the better functioning of dyslexic students in the educational system. I also wanted to present a holistic view of cooperation between specialists, school teachers and the parents of pupils with dyslexia.

Keywords: dyslexia, inclusion, special educational needs students, English as a foreign language, English as a second language, English as an additional language 